\title{
Rhodococcus imtechensis sp. nov., a nitrophenol-degrading actinomycete
}

\author{
Anuradha Ghosh, Debarati Paul, Dhan Prakash, Shanmugam Mayilraj \\ and Rakesh K. Jain \\ Microbial Type Culture Collection and Gene Bank (MTCC), Institute of Microbial Technology, \\ Sector-39A, Chandigarh -160 036, India
}

Correspondence

Rakesh K. Jain

rkj@imtech.res.in

\begin{abstract}
A Gram-positive actinobacterium, strain RKJ $300^{\top}$, capable of utilizing p-nitrophenol and 2,4dinitrophenol, was isolated from a pesticide-contaminated site in India. The morphological and chemotaxonomic properties of the isolate were typical of members of the genus Rhodococcus. The DNA G + C content was $72 \mathrm{~mol} \%$. Strain RKJ300 ${ }^{\top}$ exhibited the highest level of sequence similarity with Rhodococcus wratislaviensis NCIMB $13082^{\top}(99 \cdot 3 \%)$, followed by Rhodococcus opacus DSM $43205^{\top}(98 \cdot 8 \%)$, Rhodococcus percolatus MBS1 ${ }^{\top}(98.6 \%)$ and Rhodococcus koreensis DNP505 ${ }^{\top}$ (98.1\%). The low levels of DNA-DNA relatedness (49-58\%) with the above micro-organisms, and the differences in the biochemical and physiological properties, suggest that strain $\mathrm{RKJ} 300^{\top}$ should be classified within a novel species of the genus Rhodococcus, for which the name Rhodococcus imtechensis sp. nov. is proposed. The type strain is RKJ300 ${ }^{\top}$ $\left(=\right.$ MTCC $\left.7085^{\top}=\mathrm{JCM} 13270^{\top}\right)$.
\end{abstract}

In recent times, the application of polyphasic procedures has led to marked improvements in the classification of the genus Rhodococcus (Goodfellow et al., 1998, 1999). At the time of writing, the genus Rhodococcus consists of more than 30 recognized species (http://www.bacterio.cict.fr/qr/ rhodococcus.html). Rhodococci are ubiquitous in the environment, but occur primarily in soils and sludges. As these micro-organisms exhibit broad metabolic diversity, particularly with respect to hydrophobic compounds, they have attracted increased interest with regard to the biochemical and genetic characterization of their metabolic capabilities, and they have also been considered to be excellent candidates for bioremediation treatments (Finnerty, 1992; Warhurst \& Fewson, 1994). In this work, a polyphasic approach was used to determine the taxonomic position of bacterial strain $\mathrm{RKJ} 300^{\mathrm{T}}$, which is capable of utilizing toxic and recalcitrant compounds such as $p$-nitrophenol and 2,4dinitrophenol as sole sources of carbon and energy.

Strain RKJ300 ${ }^{\mathrm{T}}$ was isolated from a pesticide-contaminated site in Punjab State, India, on tryptone soya agar (TSA; HiMedia) at $30^{\circ} \mathrm{C}$ by using the dilution plating technique. Subcultivation was done on TSA at $30^{\circ} \mathrm{C}$ for $48 \mathrm{~h}$ and the bacterial isolate was maintained as a glycerol stock at $-70{ }^{\circ} \mathrm{C}$. The reference strains Rhodococcus wratislaviensis MTCC

The GenBank/EMBL/DDBJ accession number for the 16S rRNA gene sequence of strain RKJ300 ${ }^{\top}$ is $A Y 525785$.

Scanning electron micrographs of strain $\mathrm{RKJ} 300^{\top}$ and a table showing fatty acid compositions are available as supplementary material in IJSEM Online.
$6421^{\mathrm{T}}$, Rhodococcus opacus MTCC $6420^{\mathrm{T}}$, Rhodococcus percolatus MTCC $6422^{\mathrm{T}}$ and Rhodococcus koreensis MTCC $6425^{\mathrm{T}}$ were obtained from the Microbial Type Culture Collection and Gene Bank (MTCC), Chandigarh, India.

The colony morphology was examined following growth of the strain on TSA at $30^{\circ} \mathrm{C}$ for 3 days. The cell morphology was investigated using light microscopy (Zeiss) at $\times 1000$ magnification and scanning electron microscopy (Stereoscan 260; Leica). Cells showing different morphological stages of the growth cycle in liquid (tryptone soya broth) (TSB; HiMedia) and solid (TSA) media were processed for scanning electron microscopy as described previously (Richard \& Wilson, 1993). Motility was checked using the method described by Skerman (1967). The Gram reaction was determined by using the HiMedia Gram staining kit according to the manufacturer's instructions. Physiological tests such as growth at different temperatures, $\mathrm{pH}$ values and $\mathrm{NaCl}$ concentrations were performed as described by Goodfellow (1986). Catalase activity and urea hydrolysis were determined as mentioned by Cowan \& Steel (1965). The ability to hydrolyse arbutin, casein, gelatin, elastin, Tween 80 and starch was examined by following the protocol of Smibert \& Krieg (1994). Nitrate reduction was determined as described by Lanyi (1987). The following tests were performed as described by Goodfellow (1986): VogesProskauer, methyl red, oxidation/fermentation, growth on citrate agar and MacConkey agar and the production of $\mathrm{H}_{2} \mathrm{~S}$ and indole. Oxidase activity was determined from the oxidation of tetramethyl- $p$-phenylenediamine dihydrochloride (Sigma) (Smibert \& Krieg, 1994). Acid 
production from various carbohydrates was determined after 3 days incubation at $30^{\circ} \mathrm{C}$, using bromocresol purple as an acid/base indicator (Gordon et al., 1974). Tests for the utilization of various substrates as sole carbon $(1 \%$, w/v) (Shirling \& Gottlieb, 1966) and sole nitrogen $(0 \cdot 1 \%$, w/v) (Williams et al., 1983) sources were carried out and the utilization results were observed over a period of 1 week. The utilization of substrates as sole carbon and energy sources was also determined by using the Biolog GP2 MicroPlate system. The plate was used according to the manufacturer's instructions, with the modification that TSA medium was used instead of Biolog Universal Growth agar medium. The inoculated plates were incubated for $24 \mathrm{~h}$ and the results were read with a MicroPlate Reader, using Microlog 4.2 computer software to perform automated reading. The strains were examined for their ability to degrade $p$-nitrophenol and 2,4-dinitrophenol by using the method described by Prakash et al. (1996) following incubation at $30{ }^{\circ} \mathrm{C}$ for 3 days. The sensitivity of the strain to various antibiotics was tested using antibiotic-susceptibility discs supplied by HiMedia.

Freeze-dried cells for chemotaxonomic analyses (excepting fatty acid studies) were prepared following growth of the strain in TSB for 4 days at $30^{\circ} \mathrm{C}$. The diagnostic cell-wall amino acids and sugars were determined using TLC as described by Staneck \& Roberts (1974). Polar lipids were extracted, examined by two-dimensional TLC and identified using the method described by Minnikin et al. (1984). Menaquinones were extracted (Minnikin et al., 1984) and separated by reversed-phase HPLC (Kroppenstedt, 1982). Mycolic acids were extracted and analysed according to the protocol of Minnikin et al. (1975). For cellular fatty acid analysis, the strains were grown on TSA at $30^{\circ} \mathrm{C}$ for $36 \mathrm{~h}$, and fatty acid methyl esters were analysed by using the Sherlock Microbial Identification System (MIDI) as described previously (Pandey et al., 2002). Genomic DNA was isolated using a Qiagen genomic DNA isolation kit. DNA-DNA relatedness was studied by using the membrane filter method (Tourova \& Antonov, 1987) as described by Shivaji et al. (1992); this was performed three times starting from the isolation of genomic DNA. The G $+\mathrm{C}$ content of the genomic DNA was determined spectrophotometrically (Lambda 35; Perkin Elmer) using the thermal denaturation method (Mandel \& Marmur, 1968).

PCR amplification of the 16S rRNA gene was performed with universal primers $27 f\left(5^{\prime}\right.$-AGAGTTTGATCMTGGCTCAG-3') and 1492r (5'-TACGGYTACCTTGTTACGACTT-3') (Escherichia coli 16S rRNA numbering system; Brosius et al., 1978). The reaction mixture contained 70 ng chromosomal DNA, 1 U Deep Vent DNA polymerase, $1 \times$ ThermoPol reaction buffer, $200 \mu \mathrm{M}$ each dNTP (New England Biolabs) and $20 \mathrm{pmol}$ each primer (BioBasic). The PCR cycling parameters consisted of an initial denaturation at $95^{\circ} \mathrm{C}$ for $5 \mathrm{~min}$, followed by 30 cycles of denaturation at $95^{\circ} \mathrm{C}$ for $1 \mathrm{~min}$, annealing at $55^{\circ} \mathrm{C}$ for $1 \mathrm{~min}$ and extension at $75^{\circ} \mathrm{C}$ for $2 \mathrm{~min}$ and a final extension for $10 \mathrm{~min}$ at $75^{\circ} \mathrm{C}$. An amplicon of approximately $1.5 \mathrm{~kb}$ was separated by gel electrophoresis, eluted using the Qiaquick gel extraction kit (Qiagen) and cloned into electrocompetent E. coli DH5 $\alpha$ cells using the SmaI-digested cloning vector pBluescript II KS(+). Transformants were selected on the basis of the blue/white screening procedure (Sambrook \& Russell, 2001). Recombinant plasmids were isolated using the QIAprep spin miniprep kit (Qiagen) and the insert was completely sequenced using five forward primers and four reverse primers, namely KS (5'TCGAGGTCGACGGTATC-3'), 27f, 357f, 704f, 1114f, 685r, 1110r, 1492r and SK (5'-CGCTCTAGAACTAGTGGATC-3') (KS and SK, vector-specific primers) (Johnson, 1994), using the dideoxy chain-termination method as described previously (Pandey et al., 2002). The 16S rRNA gene sequences of closely related taxa with validly published names were retrieved from the GenBank database using BLASTN (Altschul et al., 1997) and aligned using the CLUSTAL X program (Thompson et al., 1997); the alignment was edited manually. For the neighbour-joining analysis (Saitou \& Nei, 1987), the distances between sequences were calculated on the basis of the method of Jukes \& Cantor (1969). A bootstrap analysis of 1000 replications was performed to assess the confidence limits of the branching (Felsenstein, 1985).

Scanning electron micrographs revealed that the cells of strain $\mathrm{RKJ} 300^{\mathrm{T}}$ formed filaments or showed preliminary branching at an early phase of growth $(12 \mathrm{~h})$ and fragmented into short rods during the exponential phase $(32 \mathrm{~h})$; most cells appeared as cocci in stationary phase (64 h) (see Supplementary Fig. S1 available in IJSEM Online). Growth of the strains on minimal agar medium supplemented with $p$-nitrophenol $(0.5 \mathrm{mM})$ or 2,4 -dinitrophenol $(0.5 \mathrm{mM})$ as the sole source of carbon and energy is indicated in Table 1 . Cells of strain RKJ $300^{\mathrm{T}}$ were resistant to cephaloridin $(30 \mu \mathrm{g}$ per disc) and ampicillin $(10 \mu \mathrm{g}$ per disc). They were sensitive to the following antibiotics ( $\mu \mathrm{g}$ per disc): rifampicin (5), tetracycline (30), chloramphenicol (10), chlorotetracycline (30), gentamicin (10), streptomycin (10), neomycin (30), tobramycin (10), norfloxacin (10), vancomycin (30) and oleandomycin (15). Most of the chemotaxonomic properties of the strain (presented in the species description) were typical of members of the genus Rhodococcus. No significant qualitative differences in the fatty acid profiles were found when strain $\mathrm{RKJ} 300^{\mathrm{T}}$ was compared with phylogenetically close taxa (see Supplementary Table S1 available in IJSEM Online). The DNA G $+C$ content of strain RKJ $300^{\mathrm{T}}$ was estimated to be $72 \mathrm{~mol} \%$ (mean of three replications; Table 1), a value within the range (63-72 mol\%) for the genus Rhodococcus (Takeuchi \& Hatano, 1998).

An almost-complete sequence (1510 bp) for the 16S rRNA gene of strain RKJ $300^{\mathrm{T}}$ was determined and was compared with those of other closely related taxa retrieved from the GenBank database. Sequence analysis revealed that strain $\mathrm{RKJ} 300^{\mathrm{T}}$ clustered with the members of the genus 
Table 1. Distinguishing characteristics of strain $\mathrm{RKJ}_{30}{ }^{\top}$ and the type strains of its closest phylogenetic relatives

Strains: 1, strain RKJ $300^{\mathrm{T}}$; 2, R. wratislaviensis MTCC $6421^{\mathrm{T}} ; 3$, R. opacus MTCC $6420^{\mathrm{T}} ; 4$, R. percolatus MTCC $6422^{\mathrm{T}}$; 5, R. koreensis MTCC $6425^{\mathrm{T}}$. All of the strains were found to produce acid from glucose, fructose ${ }^{a_{\star}}, \mathrm{D}$-galactose, inositol ${ }^{a}$, lactose $^{a}$, maltose $^{a}, \mathrm{D}$-mannitol ${ }^{a}$, D-raffinose, sorbitol ${ }^{a}$ and sucrose and not to produce acid from adonitol, cellobiose or dulcitol. All strains were positive for the utilization of fructose $^{a b}, \alpha$-D-glucose ${ }^{a b}$, pyruvic acid and Tween 40 as sole sources of carbon and energy (Biolog). All strains were negative for the utilization of $N$-acetyl-L-glutamic acid, adenosine $5^{\prime}$-monophosphate, $2^{\prime}$-deoxyadenosine, $\beta$-dextrin, D-fructose 6-phosphate, $\alpha$-D-glucose 1 -phosphate, L-glutamic acid, glycogen, inosine, lactamide, mannan, methyl $\alpha$-D-galactoside, thymidine, thymidine $5^{\prime}$-monophosphate and uridine as sole sources of carbon and energy (Biolog). Data were obtained from this study unless stated otherwise. Characteristics are scored as follows: + , positive; $\mathrm{W}$, weakly positive; - , negative.

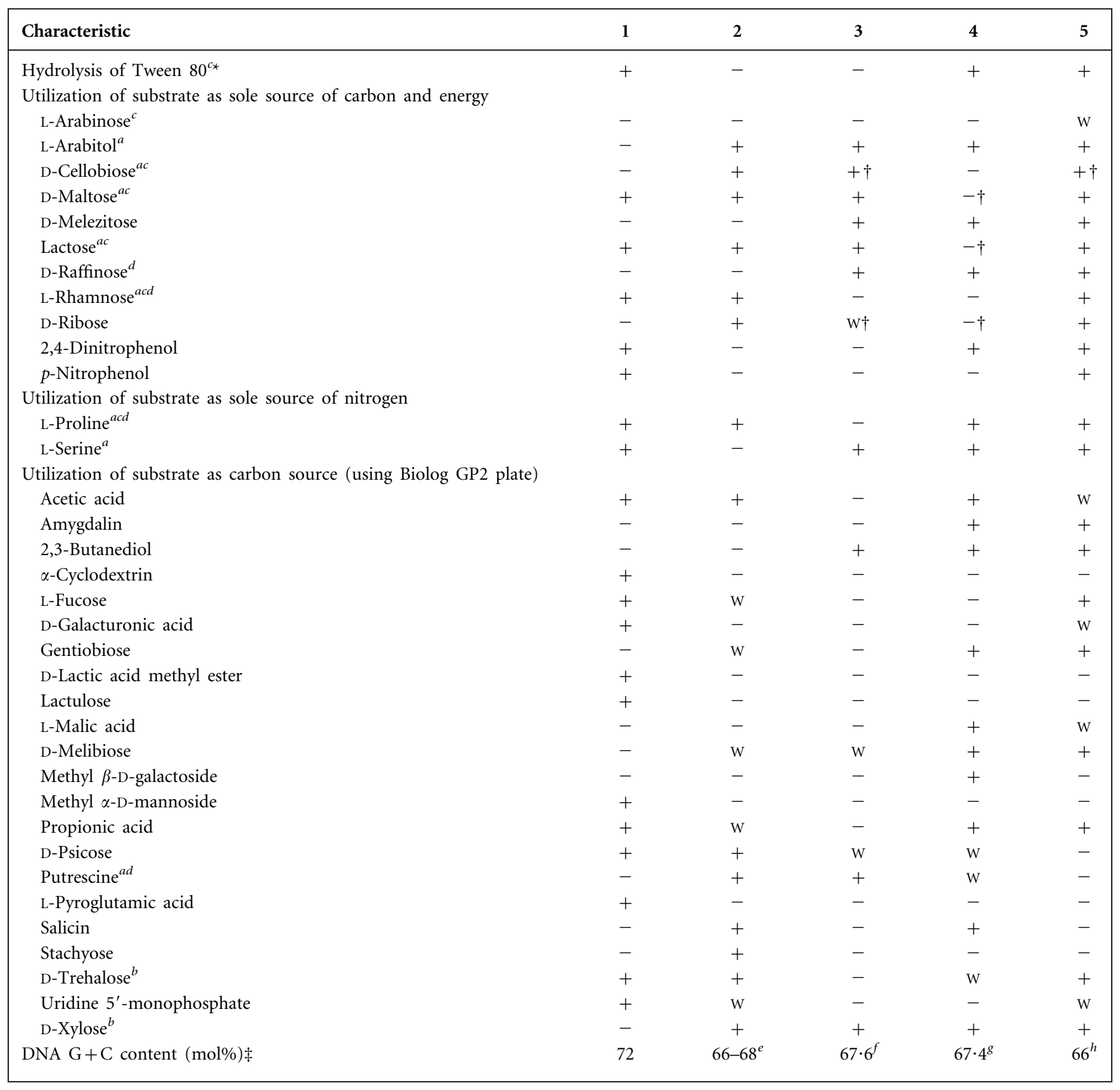

${ }^{\star}$ Tests (based on a different method) were also performed in another study as shown and gave congruent results: $a$, Klatte et al. (1994) with $R$. opacus; b, Yoon et al. (2000) with R. koreensis; c, Briglia et al. (1996) with R. percolatus; d, Goodfellow et al. (2002) with R. wratislaviensis. $\dagger$ Different results were reported by Yoon et al. (2000).

¥Data taken from: e, Goodfellow et al. (2002); f, Klatte et al. (1994); g, Briglia et al. (1996); h, Yoon et al. (2000). 


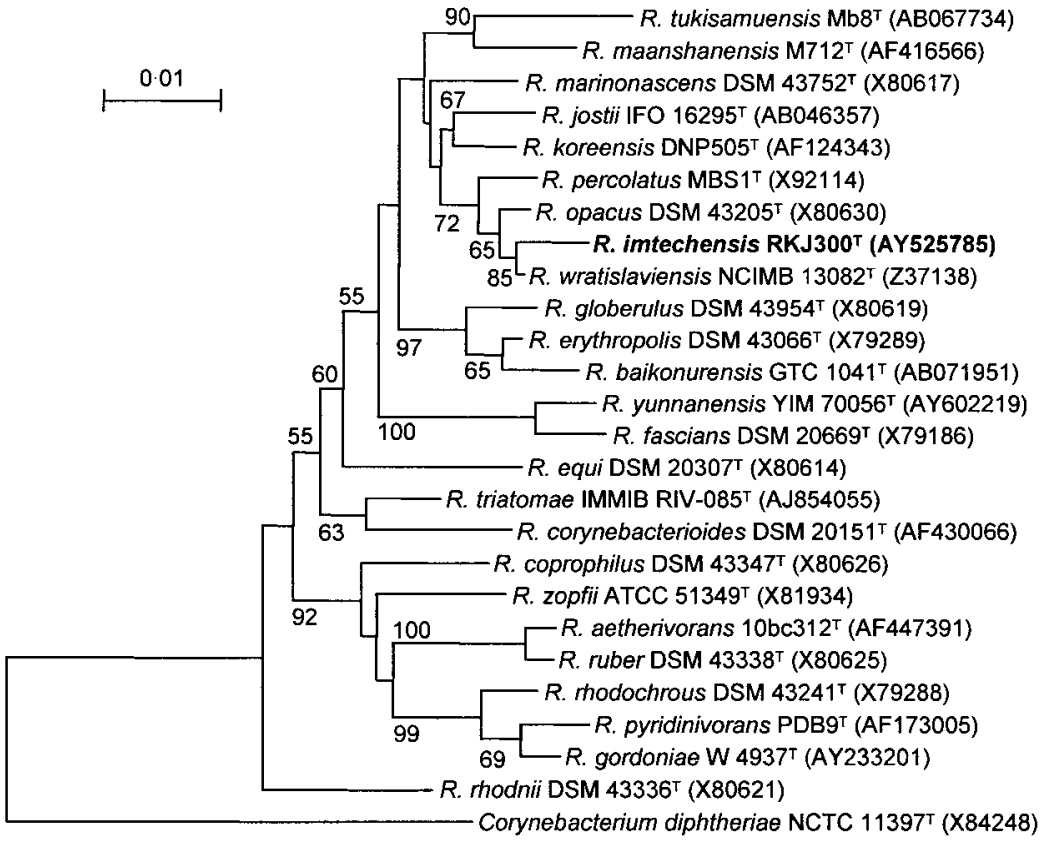

Fig. 1. Neighbour-joining phylogenetic tree, based on 16S rRNA gene sequences, showing the relationship between strain RKJ $300^{\top}$ and related type strains of Rhodococcus species. Corynebacterium diphtheriae NCTC $11397^{\top}$ was used as the outgroup. Numbers at nodes indicate levels of bootstrap support $\geqslant 50 \%$, based on a neighbour-joining analysis of 1000 resampled datasets. GenBank accession numbers are given in parentheses. Bar, 1 substitution per 100 nucleotide positions.
Rhodococcus (Fig. 1), showing the highest level of sequence similarity with $R$. wratislaviensis NCIMB $13082^{\mathrm{T}}(99 \cdot 3 \%)$, followed by $R$. opacus DSM $43205^{\mathrm{T}}(98 \cdot 8 \%), R$. percolatus $\operatorname{MBS1}^{\mathrm{T}}(98 \cdot 6 \%)$ and R. koreensis DNP505 ${ }^{\mathrm{T}}(98 \cdot 1 \%)$.

The genomic relatedness of strain $\mathrm{RKJ} 300^{\mathrm{T}}$, as revealed by DNA-DNA hybridization, was $58 \pm 1 \%$ with $R$. koreensis MTCC $6425^{\mathrm{T}}, 53 \pm 2 \%$ with $R$. opacus MTCC $6420^{\mathrm{T}}$, $51 \pm 2 \%$ with $R$. percolatus MTCC $6422^{\mathrm{T}}$ and $49 \pm 2 \%$ with $R$. wratislaviensis MTCC $6421^{\mathrm{T}}$. These data further supported the conclusion drawn by Yassin (2005) that representatives of Rhodococcus species with 16S rRNA gene sequence similarity greater than $98 \%$ share whole genomic relatedness values well below the $70 \%$ cut-off point recommended for the delineation of bacterial species (Wayne et al., 1987). In view of this, we did not investigate the DNA-DNA relatedness of strain $\mathrm{RKJ} 300^{\mathrm{T}}$ with respect to species of Rhodococcus that showed 16S rRNA gene sequence similarities below $98 \%$. The characteristics that differentiate strain $\mathrm{RKJ} 300^{\mathrm{T}}$ from closely related species are summarized in Table 1. On the basis of the data presented in this study, we conclude that strain $\mathrm{RKJ} 300^{\mathrm{T}}$ should be assigned to a novel species, for which the name Rhodococcus imtechensis sp. nov. is proposed.

\section{Description of Rhodococcus imtechensis sp. nov.}

Rhodococcus imtechensis [im.tech.en'sis. N.L. masc. adj. imtechensis pertaining to the Institute of Microbial Technology (IMTECH), where the type strain was characterized].

Gram-positive, aerobic, non-motile, catalase-positive, oxidase-negative actinobacterium that shows a hypha-rodcoccus life cycle. On TSA plates, colonies are circular, glistening, opaque, convex, creamish pink in colour and have smooth margins. Growth occurs at $15-37^{\circ} \mathrm{C}$ (optimum $30{ }^{\circ} \mathrm{C}$ ), at $\mathrm{pH} 5 \cdot 0-10 \cdot 0$ (optimum $\mathrm{pH} 7 \cdot 0$ ) and at $2 \cdot 5-5 \cdot 0 \%$ $(\mathrm{w} / \mathrm{v}) \mathrm{NaCl}$. No growth occurs on citrate agar or MacConkey agar. Tween 80 and urea are hydrolysed, but casein, gelatin, starch, elastin and arbutin are not. Methyl red, VogesProskauer and oxidation/fermentation tests give negative results. $p$-Nitrophenol and 2,4-dinitrophenol are degraded. Nitrate and nitrite are not reduced. $\mathrm{H}_{2} \mathrm{~S}$ and indole are not produced. Utilization of carbon and nitrogen sources and acid production from carbohydrates under aerobic conditions are shown in Table 1. The diagnostic cell-wall amino acid is meso-diaminopimelic acid, and arabinose and galactose are the major cell-wall sugars, indicating cellwall chemotype IV. The major isoprenoid quinone is MK$8\left(\mathrm{H}_{2}\right)$; MK- $9\left(\mathrm{H}_{2}\right)$ is present in minor amounts. The cellular polar lipid content is of type II, comprising phosphatidylethanolamine, phosphatidylinositol, phosphatidylinositol mannoside, phosphatidylglycerol and traces of diphosphatidylglycerol. The predominant fatty acids are $\mathrm{C}_{16: 0}$ $(34 \cdot 14 \%), \quad \mathrm{C}_{16: 1} \omega 7 c \quad(21 \cdot 18 \%), \quad \mathrm{C}_{17: 1} \omega 8 c \quad(15 \cdot 54 \%)$, $\mathrm{C}_{18: 1} \omega 9 c(8 \cdot 72 \%)$, 10-methyl $\mathrm{C}_{18: 0}(1 \cdot 68 \%)$ and 10 methyl $\mathrm{C}_{17: 0}(1 \cdot 55 \%)$. Mycolic acids are present. The DNA $\mathrm{G}+\mathrm{C}$ content is $72 \mathrm{~mol} \%$.

The type strain, RKJ300 ${ }^{\mathrm{T}}\left(=\right.$ MTCC $\left.7085^{\mathrm{T}}=\mathrm{JCM} 13270^{\mathrm{T}}\right)$, was isolated from a pesticide-contaminated soil in Punjab State, India.

\section{Acknowledgements}

We thank Nisha Gupta, Rajbir Singh, Abhineet Goyal and Malkit Singh for their excellent technical assistance. We also thank Pradipta Saha, Narinder K. Sharma and Janmejay Pandey for helpful discussions. We are grateful to Dr Manoj Raje for his help with electron microscopy. 
This work was supported, in part, by CSIR and DBT, Government of India. A. G. and D. P. acknowledge research fellowships awarded by CSIR. This is IMTECH communication number 019/2005.

\section{References}

Altschul, S. F., Madden, T. L., Schaffer, A. A., Zhang, J., Zhang, Z., Miller, W. \& Lipman, D. J. (1997). Gapped BLAST and PSI-BLAST: a new generation of protein database search programs. Nucleic Acids Res 25, 3389-3402.

Briglia, M., Rainey, F. A., Stackebrandt, E., Schraa, G. \& SalkinojaSalonen, M. S. (1996). Rhodococcus percolatus sp. nov., a bacterium degrading 2,4,6-trichlorophenol. Int J Syst Bacteriol 46, 23-30.

Brosius, J., Palmer, M. L., Kennedy, P. J. \& Noller, H. F. (1978). Complete nucleotide sequence of a $16 \mathrm{~S}$ ribosomal RNA gene from Escherichia coli. Proc Natl Acad Sci U S A 75, 4801-4805.

Cowan, S. T. \& Steel, K. J. (1965). Manual for the Identification of Medical Bacteria. London: Cambridge University Press.

Felsenstein, J. (1985). Confidence limits on phylogenetics: an approach using the bootstrap. Evolution 39, 783-791.

Finnerty, W. R. (1992). The biology and genetics of the genus Rhodococcus. Annu Rev Microbiol 46, 193-218.

Goodfellow, M. (1986). Genus Rhodococcus Zopf 1891, 28 ${ }^{\mathrm{AL}}$. In Bergey's Manual of Systematic Bacteriology, vol. 2, pp. 1472-1481. Edited by P. H. A. Sneath, N. S. Mair, M. E. Sharpe \& J. G. Holt. Baltimore: Williams \& Wilkins.

Goodfellow, M., Alderson, G. \& Chun, J. (1998). Rhodococcal systematics: problems and developments. Antonie van Leeuwenhoek 74, 3-20.

Goodfellow, M., Isik, F. \& Yates, E. (1999). Actinomycete systematics: an unfinished synthesis. Nova Acta Leopold NF80 (312), 47-82.

Goodfellow, M., Chun, J., Stackebrandt, E. \& Kroppenstedt, R. M. (2002). Transfer of Tsukamurella wratislaviensis Goodfellow et al. 1995 to the genus Rhodococcus as Rhodococcus wratislaviensis comb. nov. Int J Syst Evol Microbiol 52, 749-755.

Gordon, R. E., Barnett, D. A., Handerhan, J. E. \& Pang, C. H.-N. (1974). Nocardia coeliaca, Nocardia autotrophica, and the nocardin strain. Int J Syst Bacteriol 24, 54-63.

Johnson, J. L. (1994). Similarity analysis of rRNAs. In Methods for General and Molecular Bacteriology, pp. 683-700. Edited by P. Gerhardt, R. G. E. Murray, W. A. Wood \& N. R. Krieg. Washington, DC: American Society for Microbiology.

Jukes, T. H. \& Cantor, C. R. (1969). Evolution of protein molecules. In Mammalian Protein Metabolism, vol. 3, pp. 21-132. Edited by H. N. Munro. New York: Academic Press.

Klatte, S., Kroppenstedt, R. M. \& Rainey, F. A. (1994). Rhodococcus opacus sp. nov., an unusual nutritionally versatile Rhodococcusspecies. Syst Appl Microbiol 17, 355-360.

Kroppenstedt, R. M. (1982). Separation of bacterial menaquinones by HPLC using reverse phase (RP 18) and a silver loaded ion exchanger as stationary phases. J Liq Chromatogr 5, 2359-2387.

Lanyi, B. (1987). Classical and rapid identification methods for medically important bacteria. Methods Microbiol 19, 1-67.

Mandel, M. \& Marmur, J. (1968). Use of ultraviolet absorbancetemperature profile for determining the guanine plus cytosine content of DNA. Methods Enzymol 12B, 195-206.

Minnikin, D. E., Alshamaony, L. \& Goodfellow, M. (1975). Differentiation of Mycobacterium, Nocardia, and related taxa by thin-layer chromatographic analysis of whole-organism methanolysates. J Gen Microbiol 88, 200-204.

Minnikin, D. E., O'Donnell, A. G., Goodfellow, M., Alderson, G., Athalye, M., Schaal, A. \& Parlett, J. H. (1984). An integrated procedure for the extraction of bacterial isoprenoid quinones and polar lipids. J Microbiol Methods 2, 233-241.

Pandey, K. K., Mayilraj, S. \& Chakraborti, T. (2002). Pseudomonas indica sp. nov., a novel butane-utilizing species. Int J Syst Evol Microbiol 52, 1559-1567.

Prakash, D., Chauhan, A. \& Jain, R. K. (1996). Plasmid-encoded degradation of $p$-nitrophenol by Pseudomonas cepacia. Biochem Biophys Res Commun 224, 375-381.

Richard, A. W. \& Wilson, A. J. (1993). Procedures in Electron Microscopy. New York: Wiley.

Saitou, N. \& Nei, M. (1987). The neighbor-joining method: a new method for reconstructing phylogenetic trees. Mol Biol Evol 4, 406-425.

Sambrook, J. \& Russell, D. W. (2001). Molecular Cloning: a Laboratory Manual, 3rd edn. Cold Spring Harbor, NY: Cold Spring Harbor Laboratory.

Shirling, E. B. \& Gottlieb, D. (1966). Methods for characterization of Streptomyces species. Int J Syst Bacteriol 16, 313-340.

Shivaji, S., Ray, M. K., Saisree, L., Jagannadham, M. V., Seshu Kumar, G., Reddy, G. S. N. \& Bhargava, P. M. (1992). Sphingobacterium antarcticus sp. nov., a psychrotrophic bacterium from the soils of Schirmacher Oasis, Antarctica. Int J Syst Bacteriol 42, 102-116.

Skerman, V. B. D. (1967). A Guide to the Identification of the Genera of Bacteria, 2nd edn. Baltimore: Williams \& Wilkins.

Smibert, R. M. \& Krieg, N. R. (1994). Phenotypic characterization. In Methods for General and Molecular Bacteriology, pp. 607-654. Edited by P. Gerhardt, R. G. E. Murray, W. A. Wood \& N. R. Krieg. Washington, DC: American Society for Microbiology.

Staneck, J. L. \& Roberts, G. D. (1974). Simplified approach to identification of aerobic actinomycetes by thin layer chromatography. Appl Microbiol 28, 226-231.

Takeuchi, M. \& Hatano, K. (1998). Gordonia rhizosphera sp. nov. isolated from the mangrove rhizosphere. Int J Syst Bacteriol 48, 907-912.

Thompson, J. D., Gibson, T. J., Plewniak, F., Jeanmougin, F. \& Higgins, D. G. (1997). The CLUSTAL_X windows interface: flexible strategies for multiple sequence alignment aided by quality analysis tools. Nucleic Acids Res 25, 4876-4882.

Tourova, T. P. \& Antonov, A. S. (1987). Identification of microorganisms by rapid DNA-DNA hybridization. Methods Microbiol 19, 333-355.

Warhurst, A. M. \& Fewson, C. A. (1994). Biotransformations catalyzed by the genus Rhodococcus. Crit Rev Biotechnol 14, 29-73.

Wayne, L. G., Brenner, D. J., Colwell, R. R. \& 9 other authors (1987). International Committee on Systematic Bacteriology. Report of the ad hoc committee on reconciliation of approaches to bacterial systematics. Int J Syst Bacteriol 37, 463-464.

Williams, S. T., Goodfellow, M., Alderson, G., Wellington, E. M. H., Sneath, P. H. A. \& Sackin, M. J. (1983). Numerical classification of Streptomyces and related genera. J Gen Microbiol 129, 1743-1813.

Yassin, A. F. (2005). Rhodococcus triatomae sp. nov., isolated from a blood-sucking bug. Int J Syst Evol Microbiol 55, 1575-1579.

Yoon, J.-H., Cho, Y.-G., Kang, S.-S., Kim, S. B., Lee, S. T. \& Park, Y.-H. (2000). Rhodococcus koreensis sp. nov., a 2,4-dinitrophenoldegrading bacterium. Int J Syst Evol Microbiol 50, 1193-1201. 